\title{
Listy księdza Jana Piotrowskiego, „przyjaciela z Dworu”, o wojsku w obozie pod Pskowem w 1581 roku
}

Streszczenie. Problematyka życia codziennego w obozie wojskowym w epoce wczesnonowożytnej nie była, jak dotąd (poza nielicznymi wyjątkami), przedmiotem osobnego studium. Szczególnie interesujące wydaje się skupienie na tej kwestii w odniesieniu do wypraw inflanckich Stefana I Batorego, zwłaszcza ostatniej z nich (Psków - 1581 r.). Prócz oficjalnej dokumentacji o charakterze politycznych oraz stosunkowo nieźle zachowanych źródeł natury wojskowo-skarbowej, dysponujemy bowiem dziennikiem Jana Piotrowskiego, uczestnika tych wydarzeń. W formie obszernych listów informował on o przebiegu działań zbrojnych, ale również o nastrojach wśród żołnierzy. Niejednokrotnie pisał także o warunkach codziennego bytowania wojska w obozie (w marszu i podczas oblężeń), sposobach i okolicznościach zdobywania żywności, warunkach pomieszkiwania w obozie wojskowym, kwestiach sanitarnych i zdrowotnych. Jego zapiski doskonale uzupełniają diariusze Łukasza Działyńskiego i Jana Zborowskiego.

Słowa kluczowe: historia wojskowości wczesnonowożytnej, oblężenie Pskowa (1581-1582), sztuka wojenna, życie codzienne, Królestwo Polskie, Wielkie Księstwo Litewskie, Wielkie Księstwo Moskiewskie.

$\mathrm{P}$ roblematyka życia codziennego w obozie wojskowym w epoce wczesnonowożytnej nie była, jak dotąd (poza nielicznymi wyjątkami), przedmiotem osobnego studium. Szczególnie interesujące wydaje się skupienie na tej kwestii w odniesieniu do wypraw inflanckich Stefana I Batorego, zwłaszcza ostatniej z nich (Psków - 1581 r.). Prócz oficjalnej dokumentacji o charakterze politycznych oraz stosunkowo nieźle zachowanych źródeł natury wojskowo-skarbowej, dysponujemy bowiem dziennikiem Jana Piotrowskiego, uczestnika tych wydarzeń. W formie obszernych listów informował on o przebiegu działań zbrojnych, ale również o nastrojach wśród żołnierzy. Niejednokrotnie pisał także o warunkach codziennego bytowania wojska w obozie (w marszu i podczas oblężeń), sposobach i okolicznościach zdobywania żywności, warunkach pomiesz-

* Wydział Filozoficzno-Historyczny, Instytut Historii, Katedra Historii Średniowiecznej, e-mail: bow0@poczta.onet.pl. 
kiwania w obozie wojskowym, kwestiach sanitarnych i zdrowotnych. Jego zapiski doskonale uzupełniają diariusze Łukasza Działyńskiego i Jana Zborowskiego. Te, choć dotyczą kampanii wojennej o rok wcześniejszej (tzw. wyprawa wielkołucka, 1580 r.), jeśli chodzi o wymowę niektórych stwierdzeń, potwierdzają liczne obserwacje Jana Piotrowskiego.

Ksiądz Jan Piotrowski w czasie wyprawy pskowskiej Stefana I Batorego był sekretarzem w kancelarii królewskiej, miał zatem do czynienia z kanclerzem, ale i hetmanem koronnym Janem Zamoyskim. Z kilku listów wynika, że łączyło go z Zamoyskim szczególne porozumienie, dzięki czemu Piotrowski nie tylko miał dostęp do oficjalnych informacji wynikających z dokumentacji kancelaryjnej, lecz także znał na bieżąco wszystkie nowiny dotyczące prowadzenia wojny, przyjmowania i odprawiania posłów, wreszcie świetnie orientował się w nastrojach, plotkach, niesnaskach i nastawieniu poszczególnych osób do podejmowanych przez króla i kanclerza-hetmana działań. To właśnie Piotrowski zanotował opowieść o żołnierzach litewskich, którzy powtarzali kuplet na temat Zamoyskiego:
Z łotra pan, z klechy pleban, żak sądzi, desperat rządzi, klecha hetmani, Panie Boże, racz być $\mathrm{z}$ nami ${ }^{1}$.

Kanclerz, nie pozostał dłużny i nakazał spisanie odpowiedzi „[...] w ten sens [...] że każdy Litwin abo bękart abo złodziej”’2. O czym zresztą w tajemnicy poinformował Piotrowskiego, prosząc jednocześnie o zachowanie tego dla siebie. Z przywołanego fragmentu listu widać, że sekretarz nie przejął się prośbą Zamoyskiego i niezwłocznie doniósł o tym Andrzejowi Opalińskiemu³.

Choć Piotrowski wywodził się z mało znaczącej rodziny szlacheckiej z powiatu kościańskiego, to zapewne dzięki protekcji kanclerza wielkiego koronnego Andrzeja Opalińskiego uzyskał wstęp do kancelarii, gdzie - jak się wydaje - dzięki swej pracowitości i sumienności wypracował sobie mocną pozycję oraz stopniowo zaczął gromadzić zaszczyty (m.in. kanonika krakowskiego w 1576, gnieźnieńskiego w 1579 i dziekana poznańskiego w 1584$)^{4}$. Listy pisane pod pseudonimem „przyjaciela z Dworu” skierowane były właśnie do marszałka koronnego.

1 J. Piotrowski, Dziennik wyprawy Stefana Batorego pod Psków [dalej: Piotrowski], wyd. A. Czuczyński, Kraków 1894, s. 138.

${ }^{2}$ Piotrowski, s. 139.

3 Ibidem.

${ }^{4}$ W. Dworzaczek, Piotrowski Jan, [w:] Polski stownik biograficzny, t. XXVI, Wrocław 1981, s. 474-476; A. Czuczyński, Przedmowa, [w:] Pi otrowski, s. X-XI; W. Li poński, 


$$
* * *
$$

Problemem porządku obozowania w świetle wojskowych pism normatywnych z okresu panowania ostatnich Jagiellonów zajmowałem się już w innym miejscu ${ }^{5}$. Jednak tamto spojrzenie zostało ukształtowane przez lekturę oficjalnych zaleceń i postulatów środowiska określającego warunki życia obozowego. Relacja Piotrowskiego jest natomiast zupełnie innego rodzaju podstawą źródłową. Po pierwsze, była spisywana na bieżąco, trudno zatem podejrzewać jej autora o zakrojone na szerszą skalę manipulacje, mające na celu np. stworzenie triumfalistycznego obrazu armii koronnej i litewskiej lub odmalowanie jej nieskuteczności, również w zakresie organizacji siły zbrojnej. Zresztą sam Piotrowski zanotował, że: „Na tegorocznej wojnie będąc, cokolwiek się na niej działo, a ja też wiedzieć będę i do-

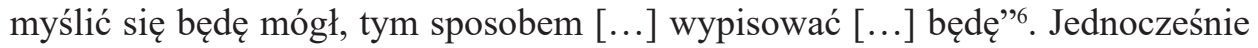
zaznacza: ,[...] o to jedno [...] proszę, aby i pisanie moje do cudzych rąk nie przychodziło [...]"’7. Skoro zatem autor prosił o dyskrecję, mógł ewentualnie obawiać się zdemaskowania, toteż można przyjąć, iż w swych listach, tworzących dziennik wyprawy Stefana Batorego pod Psków, nie musiał zachowywać oficjalnej poprawności oraz chyba nie ulegał skłonności do autocenzury. Sekretne pisma pozwalały na większą swobodę wypowiedzi niż oficjalne listy tworzone w kancelarii. Innymi słowy, o ile badanie pism normatywnych pozwoliło określić zalecenia i postulaty, o tyle opowieść Piotrowskiego jest dobrym źródłem do przeprowadzenia badania o charakterze jakościowym, mającego na celu uzupełnienie omówionego już wcześniej zagadnienia. Zależy mi szczególnie na uwypukleniu właśnie tego wątku, jako że relacja Piotrowskiego, choć znana i przywoływana w literaturze przedmiotu od dawna, pod takim kątem nigdy nie była wykorzystywana.

Zagadnienia dotyczące życia w obozie wojskowym, które wyłaniają się z pism normatywnych jako dominujące, można w zasadzie podzielić na trzy grupy. Są to przede wszystkim kwestie szeroko rozumianej aprowizacji (zapasy żywności i paszy, pozyskiwanie/picowanie i dystrybucja w obszarze objętym działaniami wojennymi, ochrona podczas picowania). Druga grupa zaleceń dotyczyła spraw sanitarnych, począwszy od zabiegów mających na celu uniknięcie zarazy, a skończywszy na pochówkach zmarłych. Trzeci zaś problem to sprawy związane z obecnością kobiet w obozie wojskowym. Te trzy kwestie znajdują swoje odbicie również w relacji Piotrowskiego, z tym, że sekretarz królewski dostrzegł o wiele więcej problemów życia wojska w obozie, niż czyniły to artykuły wojskowe.

Zapomniany wielkopolanin - ksiądz Jan Piotrowski - sekretarz kancelarii królewskiej. Pasek XVI wieku, „Pamiętnik Biblioteki Kórnickiej” 2009, z. 29, s. 141-171.

${ }^{5}$ A. B ołdyrew, Porzadek obozowania $w$ wojskowych pismach normatywnych za ostatnich Jagiellonów, [w:] Studia nad staropolska sztuką wojenną, t. V, red. Z. Hundert, K. Żojdź, J.J. Sowa, Oświęcim 2017, s. 12-20.

${ }^{6}$ Piotrowski, s. 8.

7 Piotrowski, s. 8. 
Wspomina o wpływie alkoholu na żołnierzy, warunkach socjalno-bytowych, jak również decydującym znaczeniu pogody. Przytacza dłuższe opowieści związane z brakiem dyscypliny, awanturami i zwadami, które wybuchały niekiedy z zupełnie błahych przyczyn. Pisał także o kłopotach z rozmierzeniem placu pod obóz i jego założeniem, o chorych i rannych żołnierzach, ale i dostojnikach ${ }^{8}$.

\section{Aprowizacja (picowanie)}

Zapewnienie wojsku dostępu do odpowiedniej jakościowo żywności składano na barki przekupniów/karczmarzy, ciągnących za armią. Zapewne dlatego najczęściej normatywy skupiały się na ich ochronie, a nie organizacji systemu zaopatrzenia wojska. Stąd też wydawane w kolejnych latach przepisy grożące karą śmierci każdemu, kto zaatakowałby sprzedawcę, lub samodzielnie próbował prowadzić handel $^{9}$. Jednocześnie przekupnie „Picia i inszych rzeczy ku żywności aby inak nie śmieli przedawać, jedno jako ustawa, ani miar ustawionych aby nie śmieli odmieniać, pod srogim karaniem, czego starszy hetmański będzie doglądać wiernie a pilnie"10. Swoistą gwarancją opłacalności handlu wojennego był zakaz kontaktów żołnierzy z okoliczną ludnością w promieniu 4 mil od obozu ${ }^{11}$. Innymi słowy, przynajmniej formalnie, próbowano gwarantować handlarzom monopol na dostawy żywności ${ }^{12}$. Surowo również karano wszelkiego rodzaju przejawy łupiestwa, którego wojsko dopuściłoby się na miejscowej ludności ${ }^{13}$.

W praktyce, opisywanej przez Piotrowskiego, kwestie te wcale nie były tak nieskomplikowane. 20 czerwca 1581 r., jeszcze w Wilnie, notował: ,Wilno żołnierzów pełno, by natkał; drogość wielka [...]"14. Zatem najwyraźniej oficjalnie gwarantowany system zaopatrzenia nie był wystarczająco sprawny. Pomiędzy 29 lipca a 5 grudnia wątek ten powrócił przynajmniej 13 razy. O ile początkowo liczono na stosunkowo niewielką odległość Pskowa od granicy Wielkiego Księstwa Litewskiego i związaną z tym nadzieję na stosunkowo dobre zaopatrzenie, o tyle już 27 sierpnia była „Drogość okrutnie wielka, zwłaszcza na chleb a na piwo, a jako

${ }^{8}$ Vide także H. Kotarski, Wojsko polsko-litewskie podczas wojny inflanckiej 1576-1582. Sprawy organizacyjne. Część V, „Studia i Materiały do Historii Wojskowości” 1972, t. XVIII, cz. 2, s. 90-91.

9 S. Kutrzeba, Polskie ustawy i artykuty wojskowe od XV do XVIII wieku, Kraków 1937, nr 11, pkt 18; Ł. D zi ałyń s ki, Dyaryusz oblężenia i zdobycia Wieliża, Wielkich Łuk i Zawołocia od dnia 1 Sierpnia do 25 Listopada 1580 r. pisany przez [...] starostę Kowalskiego i Brodnickiego, [w:] Sprawy wojenne króla Stefana Batorego. Dyaryjusze, relacyje, listy i akta z lat 1576-1586, wyd. I. Polkowski, Kraków 1887, s. 205, 207.

${ }^{10}$ S. Kutrzeba, op. cit., nr 14, pkt 42.

${ }^{11}$ Ibidem, nr 14, pkt 43.

${ }_{12}$ A. Bołdyrew, op. cit., s. 15-16.

${ }^{13}$ Piotrowski, s. 49.

${ }^{14}$ Piotrowski, s. 5. 
to oboje dobre a chędogie! Oj nie! Nie dziw, że się choroby wszczynają"15. Dzień później ,Narzekają ci Niemcy, że od 4 dni nie jedli chleba, ale i my go nie mamy. Bochenek tak wielki, jako za pół grosza w Poznaniu, płacimy po 5 groszy, a sprosnego, plugawego, z otrąb, aż strach” i dalej: ,Wielki nierząd, szynkarze, przekupnie bezmiernie łupią"16. Sytuacja taka doprowadziła do tego, że „Żołnierze, to jest rotmistrze, opowiadają się, że im towarzysze dalej służyć nie chcą. Powiadają, że ku zimie przez głód wytrwać nie chcą"17. Drożyzna, brak podstawowych produktów żywnościowych w odpowiedniej ilości oraz stopniowe zniechęcenie przedłużającą się wojną wpływały destruktywnie na morale wojska. Dodatkowym czynnikiem zniechęcającym były nadużycia przedstawicieli władzy. Ewidentnie wbrew postanowieniom artykułów dowództwo tolerowało zachowanie starosty zamkowego w Zawołociu w 1580 r., który ,[...] każdą rzecz [...] sam szynkował; przywiózł co na targ kto, on zakupił a żołnierzom przedawał [...]"18.

Obrazu obozującego wojska dopełniają zdarzenia, które w pośredni sposób dowodzą trudności, z jakimi musieli się borykać dowodzący. Nie tylko bowiem walka w czystej postaci stanowiła o codzienności wojska. 6 lipca 1581 r. uciekający z jednego z okolicznych zamków żołnierze moskiewscy trafili na pasące się bydło i konie dwóch rotmistrzów piechoty. „Zabrali go nie mało i ludzi kilka zabrali"19. Dowodzi to, że oblężenie zamku nie oznaczało automatycznie panowania nad całą okolicą. Oblegający nie tylko podejmowali próby sforsowania kolejnych kurtyn zamkowych, lecz także musieli pilnować własnego zaplecza.

Zupełnie absurdalna sytuacja miała natomiast miejsce 3 listopada 1581 r., kiedy to obrońcy Pskowa byli przekonani, że nastąpił szturm. Wykutą przez węgierską piechotę dziurę w murze zatarasowano konstrukcją drewnianą, którą wypełniały worki z solą, ,[...] a iż nie często z nią jadają [...]", niektórzy żołnierze polscy i węgierscy zaczęli wyciągać worki. ,Wnet się drudzy w obozie dowiedzieli. Biegł, kto mógł, nachutniej do szańców. [...] Jedni się bili z Moskwą, drudzy sól brali" ${ }^{20}$. Podobnie zresztą rzecz się miała, kiedy oblegający odkryli warzywa rosnące w opuszczonych ogrodach wokół murów miejskich,,$-[\ldots]$ po kapusty byli poszli $[\ldots]^{\prime \prime 21}$.

Przedłużające się oblężenie doprowadziło do sytuacji, w której nawet najbardziej przewidujący zużyli wszelkie zapasy ${ }^{22}$. Wojsko było zmuszone do działania na dwa fronty. Pewna jego część podtrzymywała akcje zaczepne pod murami

\footnotetext{
15 Piotrowski, s. 63.

16 Piotrowski, s. 64.

17 Piotrowski, s. 98.

18 Piotrowski, s. 37-38.

19 Piotrowski, s. 14.

20 Piotrowski, s. 171.

${ }^{21}$ Piotrowski, s. 86.

22 Piotrowski, s. 180.
} 
Pskowa, inna z kolei zaczęła rozjeżdżać się na picowanie. I choć „,...] deszcz ustawnie z ciepłem, drogi barzo złe [... ${ }^{\prime 23}$, to żołnierze byli zmuszeni do organizowania wyjazdów w poszukiwaniu żywności i paszy. Z końcem listopada grupy zaopatrzeniowe poruszały się w promieniu około $30 \mathrm{mil}$ od obozu ${ }^{24}$. Niezależnie od przeliczenia tej wartości według systemu metrycznego (mila polska mała wynosiła $6350 \mathrm{~m}$ ), odległość podana przez Piotrowskiego musiała być przecież znaczna, choć trudno uwierzyć, by picownicy oddalali się od obozu na sto kilkadziesiąt kilometrów. Bardziej prawdopodobne jest to, że autor posługiwał się miarą mili rzymskiej (1479 m) lub geograficznej (1855 m). wówczas dystans, który musieli przebyć picownicy zmniejszyłby się odpowiednio do $45-55 \mathrm{~km}^{25}$. Jak niebezpieczne były to przedsięwzięcia, najlepiej świadczy opis takiej akcji pozostawiony przez Łukasza Działyńskiego (14-15 września 1580 r.). Osiemdziesięciu kozaków Janusza Ostrogskiego wpadło na podjazd tatarski, w wyniku czego musieli uciekać i schronić się w opuszczonej wsi. Ukryci w zabudowaniach podjęli walkę z przeważającymi siłami nieprzyjaciela. Jak zaznaczył Działyński $,[\ldots]$ tylko trzej uszli i to ranni $[\ldots]]^{\prime 26}$.

Co ciekawe, 5 grudnia Piotrowski odnotował obecność w obozie przekupniów, którzy wszczęli nocny alarm w obawie przed atakiem sił moskiewskich. Trudno natomiast określić, czym się wówczas trudnili, skoro żołnierze samodzielnie zdobywali żywność ${ }^{27}$. Być może odpowiedź kryje się w zapisce pochodzącej z diariusza Działyńskiego z wyprawy wielkołuckiej 1580 r. Przytoczył on fragment $\mathrm{z}$ artykułów hetmańskich, w którym stwierdzono, że „Żywności aby żaden od przekupniów kupować nie śmiał ani dla niej zasyłał, jedno gdy na miejsce zwieziona będzie na targ" ${ }^{28}$. Przypuszczam, że przynajmniej część karczmarzy również brała udział w wyprawach po aprowizację, zaś wojsko stanowiło swego rodzaju eskortę. Dopiero po dostarczeniu zapasów do obozu sprzedawano je na wyznaczonym placu targowym. Nie oznaczało to w żadnym wypadku, że w trakcie nie dochodziło do nadużyć i zwad. 22 września ludzie Stanisława Stadnickiego pędzący zdobyczne bydło zostali napadnięci przez kozaków marszałka wielkiego litewskiego Mikołaja Krzysztofa Radziwiłła „Sierotki”. Sprawa stanęła przed sądem hetmańskim, gdzie ostatecznie konflikt załagodzono. Jednak w czasie sporu jeden z żołnierzy Stadnickiego krzyknął do Radziwiłła: „Ty, Panie Radziwille, i nie słyszysz coć rzekł?"29. Wyraźnie zatem widać nie tylko rozluźnienie dyscy-

23 Piotrowski, s. 183.

24 Piotrowski, s. 188.

25 J. S zy mań s k i, Nauki pomocnicze historii, wyd. nowe, przejrzane i zmienione, Warszawa 2001, s. 164; D. K u p is z, Psków 1581-1582, Warszawa 2015, s. 185.

26 Ł. D ziałyńs ki, op. cit., s. 238.

27 Piotrowski, s. 194.

28 Ł. D ziałyńs ki, op. cit., s. 206.

${ }^{29}$ Piotrow ski, s. 94. 
pliny, lecz także rosnące napięcie w łonie wojsk oraz topniejący dystans między możnymi a żołnierzami. Z pewnością trudne warunki bytowe sprzyjały temu zjawisku, które - co warte uwagi - Piotrowski świetnie odczytał.

\section{Kwestie sanitarne}

W pismach normatywnych wielokrotnie zwracano uwagę na zachowanie porządku sanitarnego w obozie ${ }^{30}$. Nakazywano więc przygotowywanie osobnych miejsc poza obozem służących higienie żołnierzy oraz zakazywano zabijania bydła w kręgu obozowym. Wszelkie nieczystości należało zakopywać, zaś buntującym się przeciw tym przepisom groziła kara polegająca na oddaniu baryłki wina hetmanowi ${ }^{31}$.

Dlatego dziwić może fakt, że Piotrowski, na ogół przytaczający barwne opowieści obozowe, nie wspomniał ani słowem na ten temat. Jedynie Działyński odnotował rozporządzenie hetmańskie z 10 września 1580 r.: ,[...] kazał profossowi z trębaczem po obozie jeżdżąc wywoływać, aby żaden nie smiał blisko za obozem bydła bić, w obozie samym także, plugastwa żadnego nie czynić, któregoby ułapiono ma być srodze karan"32.

Jeszcze inną kwestią była sprawa pochówków. Piotrowski odnotował 8 września 1581 r., że w wyniku rozpoznania, dokonanego przez żołnierzy w wyłomach murów pskowskich, „dziesiątników pieszych a Węgrów zwłaszcza i Niemców zginęło dosyć. [...] Barwierzow tak wiele nie masz, coby opatrowaniu wydołali" ${ }^{33}$. Z kolei 17 września dodawał: ,[... ] rannych barzo wiele umiera. Przy namieciech barwierskich, jak na cmyntarzach, pełno grobów stoi"34. Jeśli przyjmiemy, że namioty balwierzy i medyków znajdowały się wewnątrz obozu (a tam odnoszono ofiary walk z 8 września), to pochówków zabitych również dokonywano w jego obrębie. Przy przedłużającym się oblężeniu ich liczba musiała rosnąć, zaś sam koncept zakładania cmentarza w obozie $\mathrm{z}$ sanitarnego punktu widzenia był, delikatnie mówiąc, chybiony. Nieco inaczej relacjonował to Jan Zborowski w 1580 r., kiedy pisał o ciekawskim szlachcicu, trafionym pociskiem armatnim, podczas gdy przyglądał się ostrzałowi artyleryjskiemu. Ten został pochowany ,$[\ldots]$ nad obozem w górze $[\ldots], 35$.

${ }^{30}$ A. Bołdyre w, op. cit., s. 18-20.

31 S. Kutrzeba, op. cit., nr 16, pkt 19; nr 18, art. 4, pkt 8-10; J. Tarnowski, Consilium rationis bellicae, wstęp napisał J. Sikorski, tekst dzieła do druku przygotował oraz notą wydawniczą, komentarzem i słownikiem opatrzył T.M. Nowak, Warszawa 1987, s. 175-177.

32 Ł. D ziałyńs ki, op. cit., s. 237.

33 Piotrowski, s. 81.

${ }^{34}$ Piotrowski, s. 92.

35 J. Z borowski, Dyaryusz zdobycia zamków: Wieliża, Uświaty, Wielkich Łuk, w liście [...] kasztelana gnieźnieńskiego do Piotra Zborowskiego Wojewody Krakowskiego, [w:] Sprawy wojenne..., s. 202. 


\title{
Panie wesole
}

Podobnie, jak w poprzednim przypadku, tak i tu normatywy wielokrotnie przestrzegały przed sprowadzaniem do obozu kobiet lekkich obyczajów ${ }^{36}$. W oparciu o liczne wyjątki źródłowe można stwierdzić, że wyraźnie widoczna jest chęć uniknięcia zamieszania, jakie zazwyczaj musiały wywoływać kobiety trudniące się nierządem. Obawiano się również ich swoistej ,,przedsiębiorczości” polegającej na umiejętnym przenikaniu do grup, które zupełnie legalnie mogły towarzyszyć wojsku ${ }^{37}$. Autor Dziennika nie wspomniał jednak o tym zjawisku ani razu. Opierając się tylko na jego relacji, można by powiedzieć, że problem wręcz nie istniał. Co prawda Działyński w odniesieniu do wyprawy wielkołuckiej notuje, że , $[. .$.$] wszetecznice aby za wojskiem nie szły [...] a ktoby w nierządzie ja-$ kim był doznan, oboje na garle karani być mają” i dalej: „W nieprzyjacielskiej ziemi aby nik panien nie woził [...]"38, jednak to jedynie skromne uwagi. Jak najdalszy jestem od wniosku, że problem nie istniał w ogóle w czasie wypraw Batorego, lecz znana podstawa źródłowa nie upoważnia do wyciągania szerszych wniosków.

Zaprezentowany obraz oparty na relacji Piotrowskiego do jakiegoś stopnia pokrywa się z wnioskami płynącymi z analizy normatywów wojskowych z okresu panowania ostatnich Jagiellonów. Jednak obraz ten nie jest w żadnym wypadku pełny. Dziennik Piotrowskiego daje bowiem możliwość rozszerzenia o dodatkowe wątki opisu życia obozowego na przykładzie obozu wojsk polsko-litewskich, oblegających Psków w 1581 r.

\begin{abstract}
Alkohol
W pismach normatywnych brak odniesień do spożywania alkoholu. Oczywiście można przyjąć, że wówczas alkohol pijano powszechnie, toteż nie był uznawany za jakiekolwiek zagrożenie. Mimo to, Piotrowski wspomina, jak 9 lipca 1581 r. ,[...] była zawarta rada u Króla przed obiadem w najściślejszej tajemnicy. Wszystkim do jednego wynijść kazano, nie wiem jeszcze, co tam było, a pewnie o wojnie. U P. Kanclerza jadł obiad P. Wojewoda wileński i Pan trocki i popili się tak wszyscy, że nasz Pan spał cały dzień i nie wstawał z łoża aż do samej nocy"39. Zaiste, budujący to obraz dostojników, którzy radzili o wojnie, a następnie nieustępliwie „pracowali” nad dochowaniem tajemnicy. Nadużywanie trunków nie było jednak przywarą możnych. 1 października „Przyniósł karczmarz Oglęckiego roty beczkę miodu do szańców, którą 6 drabów stawiało; drudzy się nacisnęli do
\end{abstract}

\footnotetext{
36 A. Bołdyrew, op. cit., s. 17.

37 S. Kutrzeba, op. cit., nr 15, pkt 19; nr 21, pkt 3.

38 Ł. Działyńs ki, op. cit., s. 206.

${ }^{39}$ Piotrowski, s. 15.
} 
nich; ugodził zdrajca w onę beczkę i w onę gromadę, że ich 5 zaraz zabił i trzem po ręce, po nodze utrącił, z których dwu aż dobito, bo żywi nie mogli być, a oni się rozlecieli, osobno ręce, nogi, głowy. P. Gostomski z P. Pękosławskim bliżu ich siedział, tak, że sztuka głowy przed nie padła"40. Jest to wymowny obraz może nie tyle nawet pijaństwa wśród żołnierzy, ile braku dostrzegania oczywistych wydawałoby się zagrożeń, wynikających z dekoncentracji w trakcie pobytu w strefie walki.

\section{Warunki socjalno-bytowe}

Codzienność żołnierzy żyjących w marszu lub obozie wiązała się z koniecznością nocowania w często przypadkowych miejscach. Rzecz jasna, niekiedy można było rozbić namiot, ewentualnie spać w wozie lub pod nim, ale chyba częściej zdarzały się sytuacje, które Piotrowski opisywał jako „nocleg pod sosną"41. Taka forma noclegu na świeżym powietrzu przypadła na schyłek lipca 1581 r., więc można podejrzewać, że temperatury były dla wojska znośne. Piotrowski z uznaniem pisał o królu, któremu żołnierze zbudowali w lesie szałas ze świeżych gałęzi, a władca na posłaniu z liści brzozowych ,[...] przesypia jak w najlepszym pokoju"42.

Jednak jeśli tylko warunki na to pozwalały, wojsko rozbijało namioty. 18 lipca kanclerzowi litewskiemu skradziono pieczęć. I choć historia tej kradzieży ma posmak wręcz sensacyjny, to w omawianym kontekście ważniejsze jest to, że kanclerz ,namiotek dla chłodu odpiąć kazał”43. Innymi słowy, namioty musiały dawać stosunkowo dobrą ochronę przed chłodem, pamiętać jednak trzeba, że omawiane wypadki miały miejsce pod koniec drugiej dekady lipca. Zapewne im możniejszy właściciel, tym lepszej jakości namiot i bardziej komfortowe jego wyposażenie. Choć jednocześnie autor opisywał namiot królewski (rozbity w centrum obozu): „nie wydworny, jako w drodze”44. Sytuacja znacznie pogorszyła się z początkiem października, kiedy „Śnieg spadł w nocy i mróz uderzył czysty, rządny. Namiotki nasze nie przywykły tego" 45 . Mimo to jeszcze 3 grudnia namioty zajmowane przez nieobecnego już króla stały nadal, zaś mieszkał w nich synowiec królewski ${ }^{46}$.

Po pierwszych mrozach przyszły obfite deszcze, co z kolei przyczyniło się do rozmycia dróg, ale i zmuszało żołnierzy do egzystowania w ciągłej wilgoci. Zresztą na to samo narzekał rok wcześniej Zborowski ${ }^{47}$. Krótki okres dodatnich temperatur szybko minął i żołnierze już w październiku musieli improwizować, jeśli chodzi

\footnotetext{
40 Piotrowski, s. 119.

${ }^{41}$ Piotrowski, s. 33, 34, 37.

${ }^{42}$ Piotrowski, s. 35.

43 Piotrowski, s. 27.

${ }_{44}$ Piotrowski, s. 19.

45 Piotrowski, s. 108.

46 Piotrowski, s. 193.

47 Pi otrowski, s. 201; J. Z borow s ki, op. cit., s. 196.
} 
o schronienie. „Kopiem się co żywo w ziemię, jako lisy jamy, ale z ubogimi pieszymi w szańcach, wie to Bóg, co będzie" ${ }^{48}$. Zamożniejsi już we wrześniu zaczęli budować sobie szałasy, chaty i ziemianki. Niektórzy nawet wyposażali je w piece, zresztą samemu władcy zbudowano również dom $^{49}$. W efekcie ,[...] jedno ratuszu nie masz, ale rynek i ulice już stoją i mało nie drugi Psków, jedno nie tak dostatnie". Natomiast 14 października autor zauważył, że ,[...] tu nowy Psków zakładamy w obozie. Każdy, gdzie namiot jego, abo kleć, abo budkę jaką stawia. Kiedy się ruszym, jako miasto drugie będzie" 50 .

Od 7 października panowały kolejne mrozy, zaś wojsko - najwyraźniej zupełnie do tego nieprzygotowane - poszukiwało ciepłych okryćs ${ }^{5}$. Tymczasem do obozu przybył oddział najemnych Szkotów, o których Piotrowski z przekąsem pisał: „W pończoszkach jedwabnych, w rzezanych kabacikach idą. Widzi mi się, że im studenno będzie"52. Hetman Zamoyski zezwolił nawet na kupowanie kożuchów i sukiennych okryć na kredyt ręczony przez skarb królewski ${ }^{53}$. Mrozy były chyba najczęściej wymienianą przeszkodą w życiu obozowym ${ }^{54}$. Piotrowski wspominał je wielokrotnie („O Jezu, toć haniebne mrozy i zimna przypadły!”), zaś najbardziej przejmujący opis dotyczył bezradności hetmana, który tłumaczył Królowi, że „Ludzie są tak przeciążeni, że ich do dalszej straży zmuszać nie mogę" 55 , a jednocześnie wokół obozu musiały stać oddziały dozorujące, choć „Więtsza część wojska wymarła, trzecia część chora leży; tym, co zostali, od mrozu nosy, nogi odpadają; z straży muszą pachołki na wozach zmarzłe na pół martwe do obozu odwozić" 56 . W opinii Piotrowskiego, szczególnie mało odporni na trudne warunki obozowego życia byli Niemcy: „[...] zdycha ich dosyć, a wszystko po obozie żebrzą"57. Można postawić wniosek, że brak odpowiedniej aprowizacji oraz trudne czy momentami wręcz ekstremalne warunki bytowe w znacznej mierze ograniczały sprawność armii. Zatem nie tylko brak przeszkolenia, materiałów wojennych i nieudolność dowódców mogły przyczynić się do klęski lub nadmiernego przedłużania operacji wojskowych. Zła pogoda i brak żywności mogły wyeliminować jedną ze stron konfliktu równie skutecznie, jak niepowodzenia militarne. Przykładów takich sytuacji można bez trudu doszukać się w historii działań zbrojnych.

\footnotetext{
${ }^{48}$ Piotrowski, s. 104, 107.

${ }^{49}$ Piotrowski, s. 85, 91, 105, 110.

${ }^{50}$ P i otrow s ki, s. 130. Vide: K. O le j n i k, Stefan Batory 1533-1586, Warszawa 1988, s. 228;

S. Le śn i e w s ki, Jan Zamoyski. Hetman i polityk, Warszawa 2008, s. 71.

${ }^{51}$ Piotrowski, s. 111.

${ }^{52}$ Piotrowski, s. 111.

53 Piotrowski, s. 123, 144, 151.

${ }^{54} \mathrm{P}$ iotrowski, s. 136, 137, 204, 205, 209.

${ }_{55}$ Piotrowski, s. 163.

${ }^{56}$ Pi otrowski, s. 208-209.

${ }^{57}$ Piotrowski, s. 73.
} 


\section{Awantury}

Duże nagromadzenie żołnierzy w jednym miejscu oznaczało nie tylko kłopoty z zaopatrzeniem w materiały wojenne i żywność. W tak dużej grupie wywodzącej się ze wszystkich stanów i różnych terenów, prędzej czy później musiało dojść do niesnasek, awantur i starć zbrojnych. Jeszcze przed wyruszeniem na wyprawę pskowską, Piotrowski pisał, że wokół Wilna jest niebezpiecznie, „,[..] bo w górach piesi zbijają"58. Jednak nie tylko żołnierze piechoty dopuszczali się rozbojów. Pewien dworzanin (Gołkowski) zaatakował w obozie pod Worońcem (13 sierpnia) pachołka jadącego wozem. Gołkowski był ewidentnie winien zajścia, pachołek, ranny w głowę, jedynie odpierał ataki, natomiast hetman Zamoyski jeszcze 30 sierpnia nie był zdecydowany, co począć z awanturnikiem. Ostatecznie wyproszono łaskę dla przestępcy ${ }^{59}$. Najczęściej jednak Piotrowski za zajścia w obozie i szańcach obwinia żołnierzy węgierskich, w tej opinii nie jest odosobniony w porównaniu z innymi dziejopisami ${ }^{60}$. Wspomina wielokrotnie, jak to Węgrzy napadali na picujących Polaków i Litwinów, pozbawiając ich łupów, ale i pieniędzy, broni czy ubrań. Dnia 25 sierpnia ,[...] w chałupie jednej słomą [...] otoczywszy spalili dwu, trzeci uciekł”, czy ,[...] na picowaniu pacholików [...] kilka stłukli [...]"61. Jeden z Węgrów dotknięty żartami Polaków w obecności hetmana ,[...] dał w gębę Głoskowskiemu, rotmistrzowi, drugiego ranił [...]"62. Takie przykłady można mnożyć. Autor Dziennika nie darował również Włochom. Pod datą 27 września zapisał, że „Dwaj Włosiska jakieś dwie moskiewskie dziewczęta pokupili u Kozaków, dali im za nie po rusznicy i dziś w nocy w namiecie swym [...] zgwałcić usiłowali""63.

Jednak największa zwada miała miejsce 11 października pomiędzy krajczym koronnym Jerzym Mniszkiem a znanym już z awantur Gołkowskim, który kryształową szklanicą zranił w twarz krajczego podczas zatargu o wynik gry karcianej. Wywołane zamieszanie wymusiło interwencję profosa obozowego i jego hajduków. 13 października odbył się sąd hetmański. Zamoyski, wysłuchawszy relacji zwaśnionych stron, nie podjął decyzji, kogo lub jak ukarać. Ostatecznie 17 października hetman postanowił ściąć Gołkowskiego, ten nawet spisał testament, lecz dzień później okazało się, że niecnota uciekł. Piotrowski podejrzewał, że Gołkowski, będąc dworzaninem, znalazł wśród swych towarzyszy pomoc. Cała sytuacja była podwójnie niezręczna, ponieważ w obozie obowiązywał zakaz gier hazardowych i choć przewina Gołkowskiego była oczywista, to Jerzy Mniszek

${ }^{58}$ Piotrowski, s. 5.

${ }^{59}$ Piotrowski, s. 50, 51, 52.

${ }^{60}$ A. Bołdyrew, Wegrzy w armii Stefana Batorego 1576-1586, [w:] Barbarzyńcy u bram, red. M. Franz, Z. Pilarczyk, Toruń 2012, s. 400-418.

${ }^{61}$ Piotrowski, s. 57.

${ }^{62}$ Pi otrowski, s. 65.

${ }^{63}$ Piotrowski, s. 100. 
również łamał prawo. To raz. Dwa: zbiegłego więźnia pilnowali ludzie Stanisława Żółkiewskiego, kuzyna hetmana i trudno podejrzewać, że to Żółkiewski przyczynił się do ucieczki. Natomiast sam hetman i kanclerz czuł się dotknięty postawą dworaków, a nie wypadało mu się uskarżać na nieudolność swego krewnego, czyli Żółkiewskiego właśnie ${ }^{64}$.

Warto także zauważyć ciężar spoczywający na barkach hetmana, zwłaszcza po wyjeździe króla z obozu. Będąc głównym ,sprawcą” wojska, ponosił całkowitą odpowiedzialność za ewentualne niepowodzenia. Tymczasem rozprzężenie wśród żołnierzy stopniowo postępowało, grożąc wybuchem. Toteż do jakiegoś stopnia zrozumiałe jest zachowanie Zamoyskiego, który zakazał rozbierania na opał chat pozostawionych przez wyjeżdżających, a jednak żołnierze nie usłuchali rozkazu. „Wsiadł sam P. Hetman na koń i z furyą bieżał tam”. Ludzi wiozących drewno ,[...] korbaczem zbił, stłukł”. Następnie udał się do namiotów rotmistrza Pieniążka, którego żołnierze dopuścili się nadużycia i rzekł do oficera: „Zły [...] niecnotliwy człowiecze! [...] potem za kołnierz u żupana uchwyciwszy porwał i przy koniu przez kilka staj, chcąc na koło dać wsadzić, śpieszno wiódł, że dobrą jednochodą przy jednochodniku iść musiał" ${ }^{65}$. Ten wybuch, spowodowany wielomiesięcznym napięciem, został jednak odczytany jako słabość Zamoyskiego i przyniósł efekt odwrotny od zamierzonego, albowiem „rotmistrze z tego przypadku niekontenci, szemrają"66.

$$
* * *
$$

Wszystkie przywołane przypadki pochodzą w zdecydowanej większości z jednego dzieła. Można zatem zarzucić takiej relacji albo jednostronność, albo wręcz brak znajomości rzemiosła żołnierskiego, zwłaszcza że Piotrowski był sekretarzem kancelaryjnym, a nie jednym z oficerów, czy choćby zwykłym żołnierzem. Jednak uważam, że ta słabość przekazu Piotrowskiego jest tylko pozorna. Wyraźnie bowiem widoczne jest jego zaangażowanie w sprawy wojska i powodzenie całej kampanii. Relacja Piotrowskiego jest nacechowana emocjonalnie, co - jak sądzę - tylko podnosi jej walory. Przy prawie zupełnym braku pamiętników lub dzienników wojennych pochodzących z terenów szesnastowiecznej Korony, ten autorstwa Piotrowskiego stanowi barwny wyjątek.

Zestawienie uwag Piotrowskiego z przekazem natury instytucjonalnej (artykuły hetmańskie) wyraźnie pokazuje, że spektrum problemów związanych z życiem wojska w obozie dostrzeganych przez urząd hetmański jest dalece odmienne od kwestii poruszanych przez człowieka żyjącego w obozie. Regulacje prawne w gruncie rzeczy ograniczają się do spraw aprowizacji, porządku i zachowania podstawowego bezpieczeństwa sanitarnego. Tymczasem pobyt w obozie pod

\footnotetext{
${ }^{64}$ Piotrowski, s. 119-120, 134-135.

65 Piotrowski, s. 191-192.

66 Piotrowski, s. 191-192.
} 
Pskowem nastręczał wielu innych trudności. Organizacja zaopatrzenia, poruszana w artykułach hetmańskich, potraktowana była po macoszemu, natomiast liczba wzmianek w niezbyt przecież obszernej relacji spod Pskowa wręcz przytłacza. Normatywy dużo uwagi poświęcały sprawom obyczajowości, a tymczasem Piotrowski, poza jednym wypadkiem, właściwie milczy na ten temat. Oczywiście można przyjąć tłumaczenie, że był duchownym i nie stykał się bezpośrednio z tą kwestią, ale pamiętać także trzeba, że przyjął tylko niższe święcenia duchowne, a gross jego czasu pochłaniała praca urzędnicza, nie duszpasterstwo ${ }^{67}$. Normatywy natomiast w ogóle nie wspominały o procedurach przewidzianych na okoliczność zabezpieczenia wojska przed złymi warunkami atmosferycznymi, wpływem znużenia walką na morale żołnierzy, wreszcie niesnaskami w łonie armii, najczęściej na tle etnicznym. Z tych też powodów uważam relację Piotrowskiego za wartościowy przyczynek do zagadnienia życia codziennego wojska w obozie w epoki renesansu.

\section{Bibliografia}

\section{ŹRÓDEA DRUKOWANE}

Działyński Ł., Dyaryusz oblężenia i zdobycia Wieliża, Wielkich Łuk i Zawołocia od dnia 1 Sierpnia do 25 Listopada 1580 r. pisany przez [...] starostę Kowalskiego i Brodnickiego, [w:] Sprawy wojenne króla Stefana Batorego. Dyaryjusze, relacyje, listy i akta z lat 1576-1586, wyd. I. Polkowski, Kraków 1887.

Piotrowski J., Dziennik wyprawy Stefana Batorego pod Psków, wyd. A. Czuczyński, Kraków 1894.

Tarnowski J., Consilium rationis bellicae, wstęp napisał J. Sikorski, tekst dzieła do druku przygotował oraz notą wydawniczą, komentarzem i słownikiem opatrzył T.M. Nowak, Warszawa 1987.

Zborowski J., Dyaryusz zdobycia zamków: Wieliża, Uświaty, Wielkich Łuk, w liście [...] kasztelana gnieźnieńskiego do Piotra Zborowskiego Wojewody Krakowskiego, [w:] Sprawy wojenne króla Stefana Batorego. Dyaryjusze, relacyje, listy i akta z lat 1576-1586, wyd. I. Polkowski, Kraków 1887.

\section{OPRACOWANia}

Bołdyrew A., Porzadek obozowania $w$ wojskowych pismach normatywnych za ostatnich Jagiellonów, [w:] Studia nad staropolska sztuka wojenna, t. V, red. Z. Hundert, K. Żojdź, J.J. Sowa, Oświęcim 2017, s. 12-20.

Bołdyrew A., Węrzy w armii Stefana Batorego 1576-1586, [w:] Barbarzyńcy u bram, red. M. Franz, Z. Pilarczyk, Toruń 2012, s. 400-418.

Dworzaczek W., Piotrowski Jan, [w:] Polski stownik biograficzny, t. XXVI, Wrocław 1981, s. 474-476.

Kotarski H., Wojsko polsko-litewskie podczas wojny inflanckiej 1576-1582. Sprawy organizacyjne. Czesść V, „Studia i Materiały do Historii Wojskowości” 1972, t. XVIII, cz. 2, s. 44-104.

Kupisz D., Psków 1581-1582, Warszawa 2015.

67 W. Dworzacze k, op. cit., s. 475. 
Kutrzeba S., Polskie ustawy i artykuły wojskowe od XV do XVIII wieku, Kraków 1937.

Leśniewski S., Jan Zamoyski. Hetman i polityk, Warszawa 2008.

Lipoński W., Zapomniany wielkopolanin - ksiądz Jan Piotrowski - sekretarz kancelarii królewskiej. Pasek XVI wieku, „Pamiętnik Biblioteki Kórnickiej” 2009, z. 29, s. 141-171.

Olejnik K., Stefan Batory 1533-1586, Warszawa 1988.

Szymański J., Nauki pomocnicze historii, wyd. nowe, przejrzane i zmienione, Warszawa 2001.

\section{Aleksander Boldyrew}

\section{The letters of priest Jan Piotrowski, „the one friend at the court", about the army in the military camp of Psków in 1581}

$\mathrm{T}$ he issues of everyday life in the military camp in the first part of early modern period wasn't, as long as that (instead of few exceptions), the main theme of individual study. Discussing of this problem according to Stephan Bathory's campaign in Livonia, especially the last one (Psków - 1581) is particularly interesting. The reason of that situation is fact, that we can use not only political documentary and well-preserved history sources relevant to militaries and public treasury, but also a diary of Jan Piotrowski, participant of those episodes. In many comprehensive letters he informed about the course of the military actions, but also about the moods and spirits of the soldiers. Many times he wrote about conditions of the soldiers' everyday life in the camp (during march-pastes and siege), ways and circumstances of gaining the food, conditions of living in the military camp, sanitary and health issues too. His jottings are supplied by Łukasz Działyński and Jan Zborowski's diaries.

Keywords: early modern history of warfare, Pskov siege (1581-1582), art of war, everyday life, Kingdom of Poland, Grand Duchy of Lithuania, Grand Duchy of Muscovy. 